\title{
Transformation dynamics of the natural cover in the Dry Chaco ecoregion: A plot level geo-database from 1976 to 2012
}

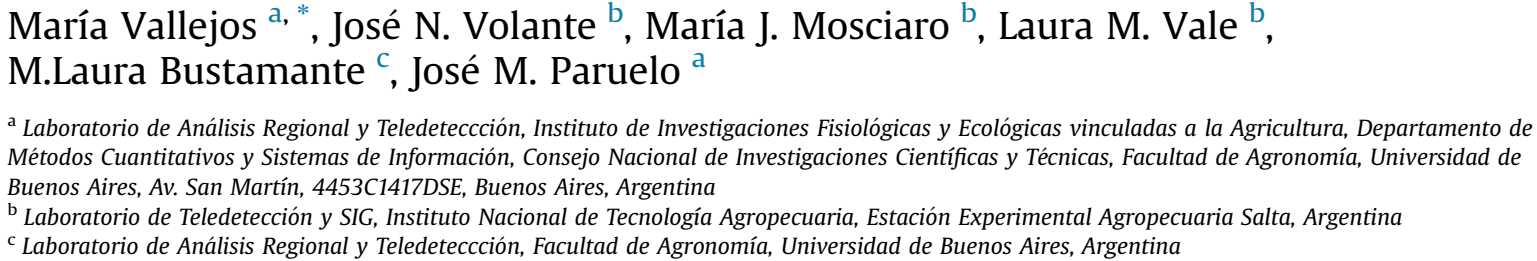

a Laboratorio de Análisis Regional y Teledeteccción, Instituto de Investigaciones Fisiológicas y Ecológicas vinculadas a la Agricultura, Departamento de Métodos Cuantitativos y Sistemas de Información, Consejo Nacional de Investigaciones Científicas y Técnicas, Facultad de Agronomía, Universidad de Buenos Aires, Av. San Martín, 4453C1417DSE, Buenos Aires, Argentina

${ }^{\mathrm{b}}$ Laboratorio de Teledetección y SIG, Instituto Nacional de Tecnología Agropecuaria, Estación Experimental Agropecuaria Salta, Argentina

${ }^{\mathrm{c}}$ Laboratorio de Análisis Regional y Teledeteccción, Facultad de Agronomía, Universidad de Buenos Aires, Argentina

\section{A R T I C L E I N F O}

\section{Article history:}

Received 10 February 2014

Received in revised form 17 October 2014

Accepted 13 November 2014

Available online $\mathrm{xxx}$

\section{Keywords:}

Deforestation

Geo-database

Monitoring

Land use change

Annual rate of forest change

\begin{abstract}
A B S T R A C T
The aim of this work was to characterize the spatial and temporal dynamics of the transformation of the natural cover in the Dry Chaco ecoregion from 1976 to 2012. Dry forests in this region have one of the highest deforestation rates in the world. We analyzed 44 Landsat scenes, including part of Argentina, Paraguay and Bolivia. The analysis was based on tracking individual transformed plots of the entire Dry Chaco region for over more than three decades using the same protocol. Until the end of 201215.8 million ha of the original habitats of the Chaco were transformed into croplands or pastures. Our study showed that the greater annual rates of transformation were observed in Paraguay, where deforestation increased dramatically in the last decade, reaching values higher than $4.0 \%$ in 2010 , the highest historical value in the entire region. The size of the transformed plots increased significantly through the studied period both in Argentina and Paraguay, while in Bolivia decreased. At the landscape level, the use of several fragmentation indices showed the disruption of the continuity and connectivity of the original vegetation. The spatially explicit description of the dynamics of transformed areas is an indispensable tool for natural resources management, territorial planning and deforestation impacts assessment. The developed geo-database is available online at http://monitoreodesmonte.com.ar/for further analyses and use.
\end{abstract}

(c) 2014 Published by Elsevier Ltd.

\section{Introduction}

South American Dry Chaco is going through a new phase of agricultural expansion and intensification that is increasing exponentially the production of commodities, but that may also compromise the provision of ecosystem services (Paruelo et al., 2011). Clearance of xerophytic forests and other native vegetation types for agriculture or cattle ranching is the dominant transformation of the landscape (Gasparri and Grau, 2009; Volante et al., 2012; Caldas et al., 2013; Volante and Paruelo, this issue). Deforestation rates are one of the highest in the world (Hansen et al., 2013), which generates a worldwide concern on the conservation of the woodlands and on the sustainability of the production

\footnotetext{
* Corresponding author.

E-mail address: vallejos@agro.uba.ar (M. Vallejos).
}

systems. Land use and land cover changes in Dry Chaco forests have become a major issue for policymakers and an area of intense political dispute (Paruelo et al., 2011; Seghezzo et al., 2011; GarcíaCollazo et al., 2013; Redaf, 2012).

Different governmental and non-governmental organizations of South American countries promote the sanction of legal instruments aimed to regulate the use of natural resources, and to support forest conservation. In December of 2004 the Congress of Paraguay sanctioned the Law No. 2524, also known as Zero Deforestation Law, which banned forest transformation in the eastern part of the country. Argentina issued Law No. 26,331, Native Forest Protection Act in November 2007, to promote the territorial planning and regulate the conservation and management of native forest (García Collazo et al., 2013). The Law No. 1700 of the Plurinational State of Bolivia, New Forest Act (issued in July 1996), was aimed to regulate property rights on forest areas for local actors. Despite these regulation attempts through legal mechanisms 
deforestation in the region follows. Moreover, there is a widespread concern on illegal deforestation and logging in Argentina (Redaf, 2012), Paraguay (Fundación Avina, 2012) and Bolivia (Andaluz and Mancilla, 2006). The ongoing land transformations generate, on the one hand, a loss of natural habitats and on the other, a fragmentation of the landscape (Gasparri and Grau, 2009). Both, in turn, have large impact on ecosystem functioning (Volante et al., 2012; Alcaraz-Segura et al., 2013a). The degree of fragmentation provides critical information to infer ecosystem characteristics (O'Neill et al., 1997). Changes in the landscape structure have direct consequences on biodiversity (Fahrig, 2003), biogeochemical cycles (Saunders et al., 1991), atmospheric dynamics (Pielke and Avissar, 1990) and water exchange (Briant et al., 2010). Land clearing increase carbon emissions (Gasparri et al., 2008), groundwater recharge and onset salt mobilization in areas where forests are replaced by annual croplands (Amdan et al., 2013).

There is a great international pressure to monitor long-term changes in forest cover (GCOS, 2004; GOFC -GOLD, 2007) and the main efforts are focused on tropical rainforests (Achard et al., 2002; Shimabukuro et al., 2004; INPE, 2008). Nevertheless, deforestation rates are particularly high in subtropical dry forests areas (FAO, 2009; Hansen et al., 2013). Several studies evaluated forest cover transformation in the Dry Chaco ecoregion (Supplementary material Table S.1); however, most of these studies had low temporal resolution or extension. A plot level geo-database for the entire Dry Chaco region that covers long term periods - more than three decades- based on the same protocol is not available. Such database is an essential input not only for basic research on the characteristics and consequences of land use and land cover change, but also for applied issues related to law enforcement or land planning.

In this paper we characterized the spatial and temporal dynamics of natural cover transformation in the South American Dry Chaco ecoregion from 1976 to 2012, using a geo-database developed with Landsat satellite imagery observation. Changes were quantified at the individual plot level. We analyzed land transformation dynamics focusing on the total transformed area, the plot size patterns and the landscape patterns of the transformed land. The developed geo-database is available for further analyses and use at http://monitoreodesmonte.com.ar/.

\section{Study area and methods}

\subsection{Study area}

The South American Dry Chaco is a vast plain comprising northwestern Argentina, western Paraguay and southeastern Bolivia, integrating an area of approx. $787,000 \mathrm{~km}^{2}$ (Olson et al., 2001). The South American Dry Chaco ecoregion includes 3 countries (primary administrative units, Argentina, Bolivia and Paraguay), 18 secondary political and administrative units (called provinces in Argentina and departments in Bolivia and Paraguay) and 175 tertiary administrative units (called departments in Argentina, municipalities in Bolivia, and districts in Paraguay). Of the total area of the Dry Chaco, 62\% is located in Argentina, including part of the provinces of Salta, Santiago del Estero, Jujuy, Tucumán, Formosa, Chaco, Catamarca, Córdoba, Santa Fe, La Rioja, San Juan and San Luis; 22\% in Paraguay, including part of the departments of Alto Paraguay, Boquerón and Presidente Hayes; and $16 \%$ in Bolivia, including part of the departments of Santa Cruz, Chuquisaca and Tarija.

The Chaco region is one of the flatter plains of the planet (Jobbágy et al., 2008). This region is part of the Rio de la Plata Basin and is crossed by the Pilcomayo, Bermejo, Juramento and Salado rivers. The climate of the Chaco is semiarid and is characterized by a strong seasonality, with high temperatures in summer and winter frost. Annual mean temperature varies from $18{ }^{\circ} \mathrm{C}$ in the southern part of the ecoregion to $26^{\circ} \mathrm{C}$ in the north, and annual mean rainfall varies from $400 \mathrm{~mm} /$ year in the center to $1000 \mathrm{~mm} / \mathrm{year}$ in the eastern and western extremes (Minetti, 1999). Because of its continental climate there are large variations in temperature between winter and summer. The months of maximum precipitation coincide with those of higher temperatures (Berbery and Barros, 2002). Rains occur in summer, from October to March, and the driest months are July and August. The predominant natural vegetation of the Chaco is open woodland or thorn forest, interspersed with grasslands (Morello et al., 2012).

This region has a significant productive potential (Lambin et al., 2013), a large biodiversity and cultural richness (TNC, 2005), but also presents high levels of poverty and inequality (Bolsi and Paolasso, 2009; Paolasso et al., 2012). Around 7.5 million people live in the Chaco, coexisting aboriginal populations with descendants of European immigrants (Criollos) (Naumann, 2006). Indigenous people and "criollos" practice a subsistence economy, including small scale agriculture, extensive ranching, hunt and gathering (Leake and De Economo, 2008). In the last decades, the area is undergoing into a rapid transformation to agribusiness (Grau et al., 2005; Gasparri et al., 2008).

\subsection{Image processing and database development}

Landsat satellite images were examined in order to identify land-clearing transitions in the period 1976-2012. Images were obtained from CONAE (National Commission on Space Activities, from Argentina), INPE (National Institute for Space Research, from Brazil) and USGS (U.S. Geological Survey, from USA). The whole area includes 44 Landsat scenes. For years prior to 2000 three periods were analyzed: 1976-1986, 1986-1996 and 1996-1999. From 2000 to 2012 land transformation dynamics was evaluated annually. We selected images with low presence of clouds, preferably corresponding to December (because most of the clearings occur during the driest winter months). Images were selected, georeferenced, ordered by date and displayed in high contrast false color composite (RGB band combination: 4-5-3) in Quantum GIS 1.8.0Lisboa. About seven hundred Landsat images have been analyzed. A list of the used images is available at http://monitoreodesmonte. com.ar/metodologia.

Landsat Multispectral Scanning (MSS) 1-3 imagery (launched at 1972 and terminated at 1983, with $60 \mathrm{~m}$ spatial resolution and 4 spectral bands) was used to detect land transformations before 1976. Scene size and path-row designations from Landsat MSS 1-3 imagery differs from that of subsequent releases. Landsat Thematic Mapper (TM) 4-5 imagery (launched at 1982 and terminated in 2013, with $30 \mathrm{~m}$ spatial resolution and 7 spectral bands) was used to detect transformations at 1986, 1996, and from 2000 to 2012. Images from Landsat Enhanced Thematic Mapper Plus (ETM+) 7 (launched at 1999 and still active, with $30 \mathrm{~m}$ resolution and 8 spectral bands, operating with scan line corrector disabled since 2003) were used to detect transformations from 2000 to 2012, as an alternative to the use of Landsat 5 .

The transformed plots were manually digitalized by visual interpretation of the last Landsat image of the study period (2012). Each individual plot was incorporated as a polygon shape into the GIS. The criterion to define plots by visual interpretation was the disruption of spatial continuity with strong evidences of human action. Transformed plots by human action are regularly shaped and have defined limits, while transformations due to natural agents (e.g. fire) are irregularly shaped. In some cases where the size of the patches was significantly large but with small defined plots inside, without hedgerows presence between them (e.g. plots 
with sugarcane in west of Tucumán transformed before 1976), plot limits were automatically traced using segmentation methods (Bhanu et al., 1995). The parameters of the segmentation methods were case defined by region according to the similarity to the real shape and size of the plots, and were revised and corrected manually afterwards.

Once the limits of the plots were drawn, the year of transformation of each plot was defined by overlaying sequentially previous Landsat images, starting from the oldest (1976). Thus, plots were identified (in the attribute table) by its year of transformation. If a polygon identified in 2012 as unit was partially transformed in several years, the 2012 plot was divided into as many plots as clearance processes occurred.

The classification was validated using high spatial resolution historical imagery from Google Earth. Five thousand random points were distributed in the study area to compare high resolution imagery with the database obtained in our study. The area covered by high spatial resolution imagery in the Dry Chaco region is $410,703 \mathrm{~km}^{2}$ (aprox. $52 \%$ of the total Dry Chaco area). The first high resolution image available in the region is from 2002. The random points were classified into 4 categories for each year from 2002 to 2012: i) Land Transformation in both the database and Google Earth (Tdb-Tge); ii) Land Transformation in the database and natural cover in Google Earth (Tdb-Nge); iii) Natural cover in the database and Google Earth (Ndb-Nge); iv) Natural cover in the database and land transformation in Google Earth (Ndb-Tge). We also compared our database with published data and contrasted transformation area estimates with the area estimated in this work.

\subsection{Data analysis}

The term "transformation" is used when there is a replacement of natural vegetation (forests, grasslands, wetlands, savannas or shrublands) by cultivated pastures or crops. The rates of transformation were calculated for five periods (pre 1976, 1976-1986, 1986-1996, 1996-2006, and 2006-2012) to evaluate tendencies. We estimated the Annual Rate of Transformation using the methodology proposed by the Food and Agriculture Organization (FAO, 1995):

$q \%=1-\left[\left(\frac{A_{2}}{A_{1}}\right)^{\frac{1}{t_{2}-t_{2}}}-1\right] * 100$

Where $q \%$ is the Annual Rate of Transformation in percentage, and 05 $A_{1}$ and $A_{2}$ represent the areas of natural habitats at dates $t_{1}$ and $t_{2}$ respectively. For the first period of analysis, we considered $t_{1}=1940$ as the year when natural vegetation removal started in the region (Morello et al., 2005). The original natural areas in the region were calculated after discounting urban areas, lakes, rivers and salines to the total area of the political administrative units. Because it is not possible to know the original forest cover of a given transformed area, $q \%$ does not represent the Annual Rate of Deforestation, but
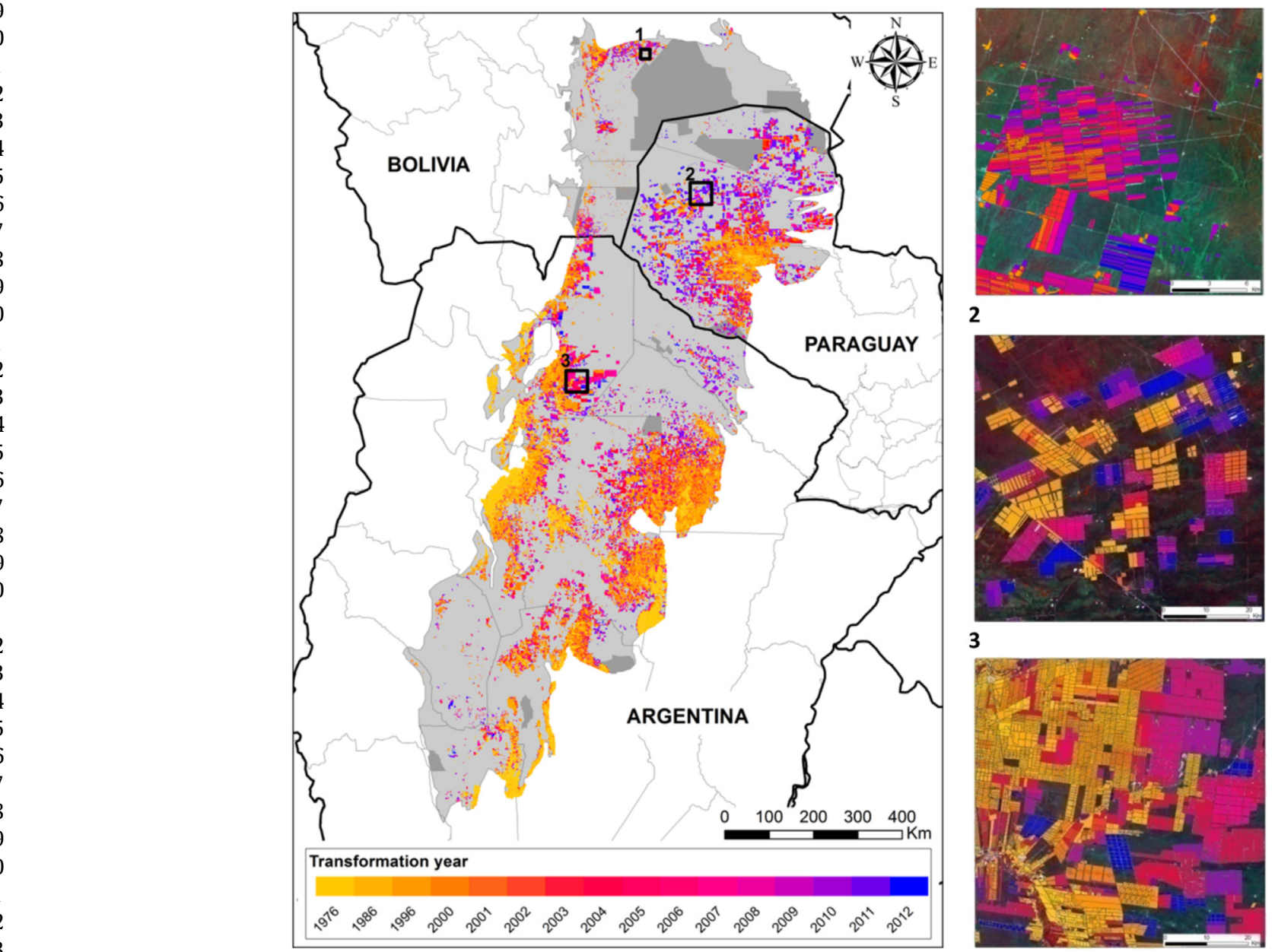

Fig. 1. Left panel: Spatial distribution of transformed areas from 1976 to 2012 in the South American Dry Chaco ecoregion. Darker gray color corresponds to protected areas inside the region. Right panel: Detail of the transformed plots in three zones from Bolivia (1), Paraguay (2) and Argentina (3). 


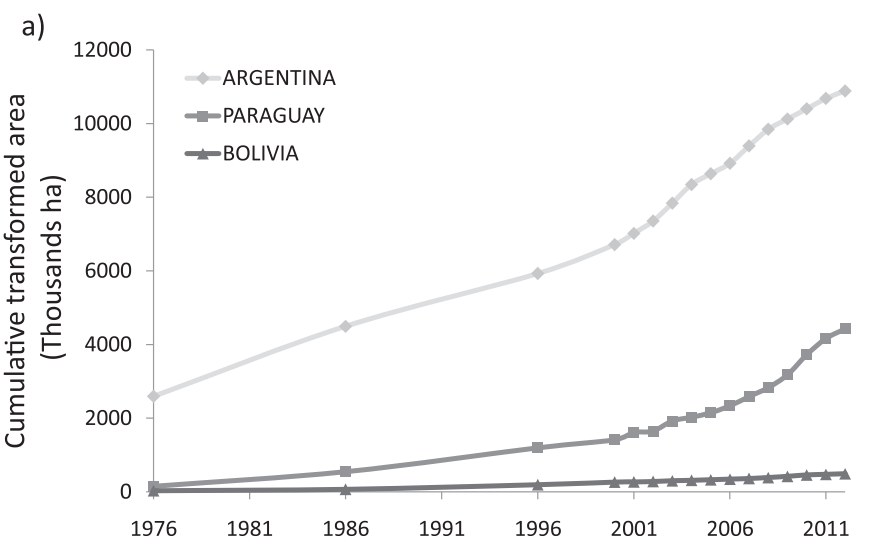

b)

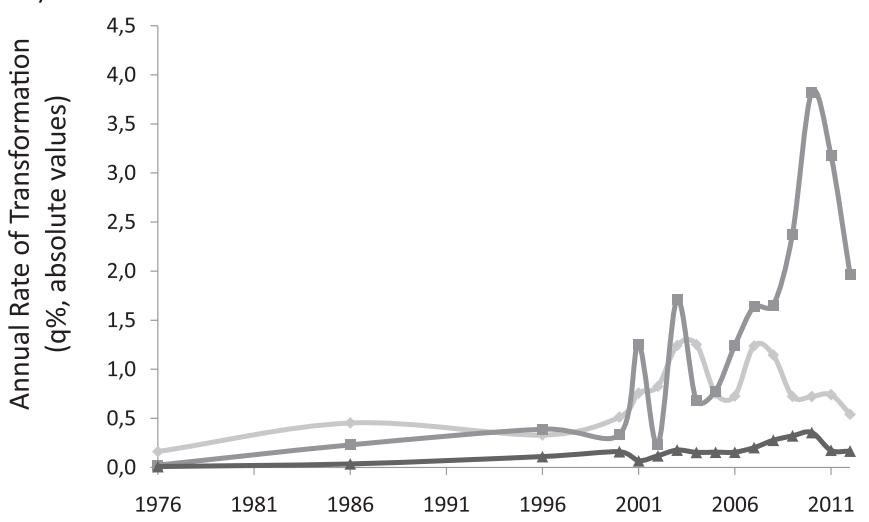

Fig. 2. (a) Cumulative transformed area and (b) Annual Rate of Transformation " $q \%$ " (FAO, 1995) as a function of the time from 1976 to 2012 at country level in South American Dry Chaco ecoregion.

the Annual Rate of Transformation. We employ $q \%$ as positive values for a better representation and understanding. $q \%$ is a widely used rate, as it weights the transformed area by the initial natural area and allows comparing rates in other locations around the world. We evaluated trends according to the best fit model based on the coefficient of determination for primary and secondary administrative units.

Plot-scale level analysis was performed by analyzing individual Plots (productive units, in most of the cases). Landscape patterns were analyzed observing transformed land patches dynamics for each period. Patches are Plots aggregated at $200 \mathrm{~m}$, i.e. without considering hedgerows between transformed Plots.

Landscape fragmentation refers to a disruption in the continuity of natural cover. It is the process where a landscape matrix is progressively subdivided into smaller and more isolated patches (Baldi et al., 2006; Gasparri and Grau, 2009). Landscape patterns of the transformed land were quantified using several indices, since no single metric can capture the complexity of the spatial arrangement of the patches (Riitters et al., 1995). Metrics to measure landscape fragmentation usually make reference to the changes in a matrix of the natural cover, but in this case, the metrics refer to the transformed Patches, what gives an idea of the accumulated impact of the transformations. Analysis of the landscape dynamics was based on a set of "Patch-based" landscape metrics at country level: total area transformed (TA), mean patch size (MPS), percentage co-variation of MPS (PSCOV), number of patches (NUMP), density of patches (DENS), total edge (TE) and Mean Shape Q1 Index (MSI) (Mc Garigal et al. 2002; Pinto-Ledezma and Ruiz, 2010). This metrics encompass essential aspects of ecosystem structure and functioning. TA of patches has effects on water, energy and nutrients cycling. MPS, NUMP have implications on the disruption of landscape continuity and connectivity, and the minimum area requirement for species survival and ecosystem functioning. PSCOV is a measure of the variability and distribution of the patches size. DENS is defined as the number of patches per unit area, which facilitates comparisons among landscapes of varying size, and is a good indicator of fragmentation (McGarigal et al., 2002). TE has implications for interior sensitive species and ecosystem integrity (Broadbent et al., 2008). MSI describe shape complexity and the compactness of patch shape. Specifically, MSI quantifies the amount of edge present in a class relative to what would be present in a class of the same area but with a circular shape. Thus, the index equals 1 for circle patches of any size and increases without limit as the patch becomes increasingly irregular.

\section{Results}

\subsection{Evaluation of the database}

The overall accuracy of the classification was $97.8 \%$. User's and producer's accuracies are balanced for "Transformation" and "Original Cover" classes. Accuracy for individual years, varied between $95.6 \%$ and 99.2\%. The estimated error matrix and accuracy for each year are shown in the Supplementary material (Table S.2 and S.3).

We compiled 18 published articles or reports that include classifications of transformed, deforested or cultivated area in the Dry Chaco ecoregion in this work (Table S.1 of the Supplementary material). These classifications cover different spatial and temporal extensions than our database. Fifteen of the classifications were realized using Landsat imagery, while three of them were based on MODIS imagery. Ten classifications resulted from visual interpretation, and the remaining by digital classifications, either they were supervised (5), unsupervised (2) or a combination of both (1).

Only two deforestation databases are available online: the global maps of forest cover change made by Hansen et al. (2013), which is available in raster format; and the data produced by Guyra Paraguay (Fundación Avina, 2012; Cardozo et al., 2013; Caballero et al., 2014), which is available in KMZ format but without an accuracy assessment.

The different spatial and temporal extensions of the analysis precluded a comparison with each single available product of land transformation. We made a comparison with the data provided by Hansen et al. (2013), Clark et al. (2010) and Boletta et al. (2006). For the same area (the Dry Chaco) the transformed area in our database was $10.0 \%$ higher than the reported by Hansen et al. (2013) (6.0\% when polygons were rasterized at $30 \times 30 \mathrm{~m}$ pixel size), $1.5 \%$ higher than Clark et al. (2010), and 0.2\% smaller than Boletta et al. (2006) (See Table S.1 Supplementary material).

\subsection{Dynamic of land transformation}

The total transformed area in Dry Chaco by the end of 2012 totalized15.8 million ha (Fig. 1). This area corresponds to the $20.7 \%$ of the natural area in the whole ecoregion. Natural areas transformed in Argentina, Paraguay and Bolivia represent the 68\%,27\% and $4 \%$ respectively, of the total area transformed (Fig. 2a). The Annual Rate of Transformation $q \%$ had the highest values in Paraguay since 2009, reaching values over $4.0 \%$ in 2010, the highest historical value in the entire region (Fig. 2b).

Considering the second level administrative units, Santiago del Estero contributed with $23 \%$ of the total transformed area, followed by Boquerón, Salta, Chaco and Alto Paraguay, which contributed respectively with a $17 \%, 12 \%, 10 \%$ and $8 \%$ of the total transformed 

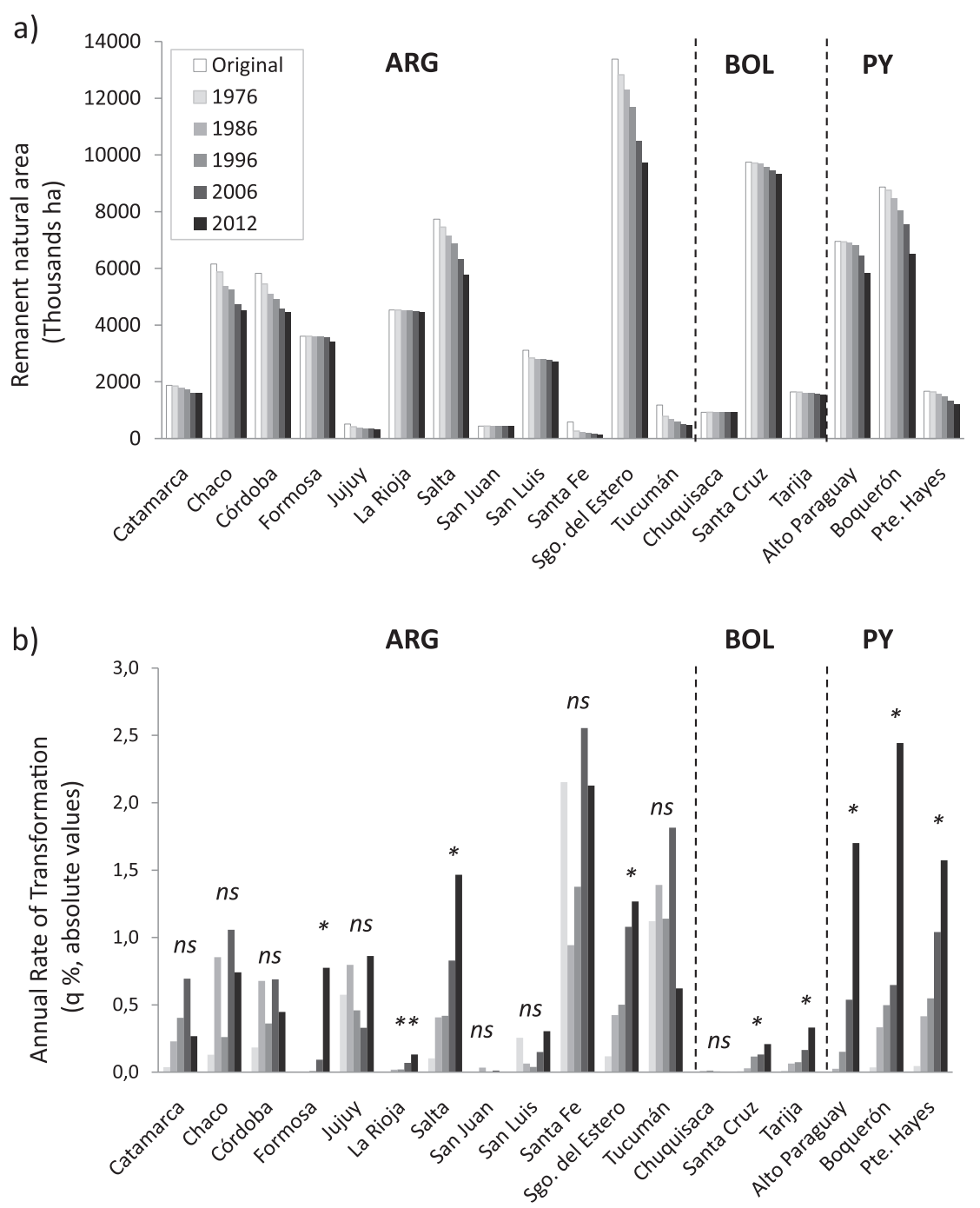

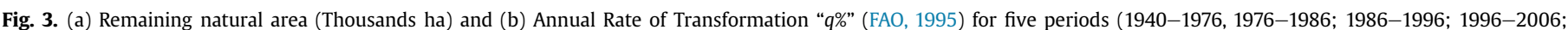

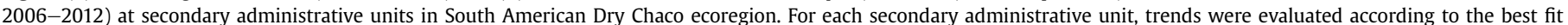
model based on the coefficient of determination. ns: not significative regression, ${ }^{* *}$ : linear regression, *: second order polynomial regressions.

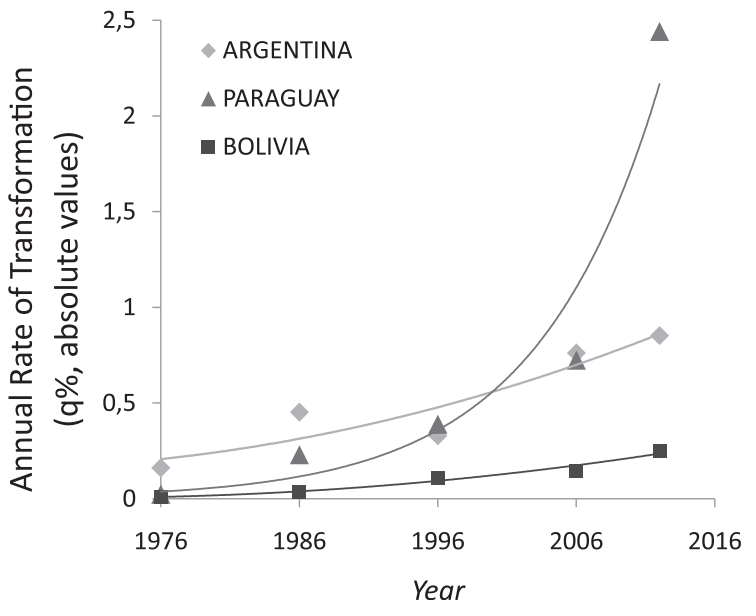

Fig. 4. Annual Rate of Transformation “q\%" (FAO, 1995) for five periods (1940-1976, 1976-1986; 1986-1996; 1996-2006; 2006-2012) at country level in South American Dry Chaco ecoregion.

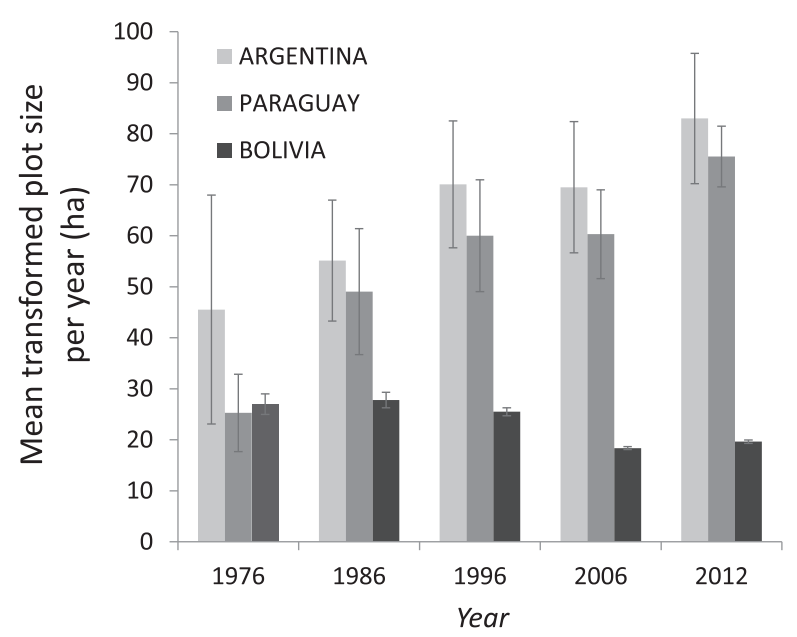

Fig. 5. Mean transformed plot size per year evolution from 1976 to 2012 at country level in South American Dry Chaco ecoregion. Error bars represent SE. 

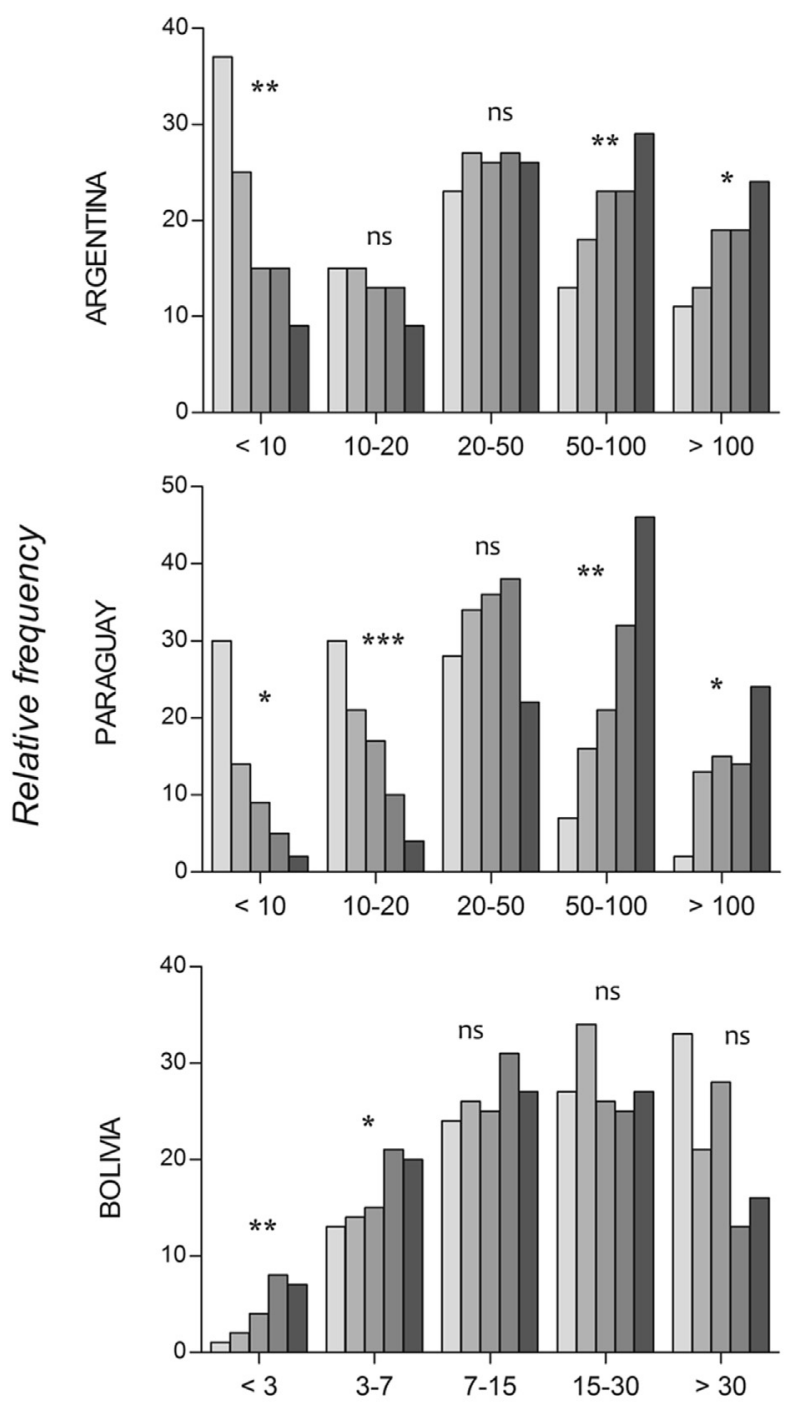

Transformed plot size (ha)

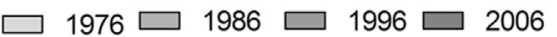

2012

Fig. 6. Relative frequency (to each year) distribution for different plot sizes categories of transformed areas from 1976 to 2012 at country level in South American Dry Chaco ecoregion. ns: not significative regression, ${ }^{*}: p<0.5,{ }^{* *}: p<0.05,{ }^{* * *}: p<0.01$.

area respectively (Fig. 3a). The Annual Rate of Transformation $q \%$ showed a significant increasing trend from 1976 to 2012 in Formosa, La Rioja, Salta, Santiago del Estero, Santa Cruz, Tarija, Alto Paraguay, Boquerón and Presidente Hayes. Except for La Rioja (showing a linear increase), trends were exponential (Fig. 3b).

An increasing positive trend of $q \%$ values was observed for the entire region, resulting in averages increments since 1976 of about $0.026 \%$ per year. Paraguay showed an exponential growth in $q \%$, presenting average increments of about $0.07 \%$ per year. Argentina and Bolivia presented averages increments in $q \%$ of about $0.02 \%$ and $0.01 \%$ per year, respectively (Fig. 4 ).

\subsection{Plot size patterns at country level}

Mean plot size (MPS) was, on average, bigger in Argentina $(61.99 \pm 0.29 \mathrm{ha})$ than in Paraguay $(54.03 \pm 0.27 \mathrm{ha})$ and Bolivia $(33.39 \pm 0.25$ ha). Moreover, MPS had a positive trend from 1976 to
2012 for Paraguay ( $b_{1}=1.13 \pm 0.02$ ha/year) and Argentina ( $b_{1}=0.82 \pm 0.02$ ha/year), while for Bolivia, had a negative one $\left(b_{1}=-0.52 \pm 0.03 \mathrm{ha} /\right.$ year) (Fig. 5).

The relative frequency of small plots (less than $20 \mathrm{ha}$ ) decreased and the relative frequency of large plots (more than 50 ha) increased throughout the study period (1976-2012) for Argentina and Paraguay. For Bolivia the trends were the opposite, besides plot sizes were smaller than in the other countries (Fig. 6).

\subsection{Patch-scale level analysis of the transformed area at the country level}

On average, Paraguay had larger Patch size ( $3513 \pm 742$ ha), than Argentina (1284 \pm 115 ha) and Bolivia (361 \pm 70 ha). Patch size at landscape level was 10 times bigger in Paraguay than in Bolivia, and 3 times bigger compared to Argentina. The Number of Patches, its co-variation, and the Density of Patches (patches per unit area) increased as the Total Area transformed increased from 1976 to 2012. Mean Patch Size (ha) and the Total Edge $(\mathrm{m})$ showed also an increasing trend, except between the first and second period analyzed for Bolivia. The Mean Shape Index showed high values in the first period for Bolivia and Paraguay-indicating increases in complexity of patches-, and the opposite pattern for Argentina (Table 1).

The relative frequency of small patches of transformed areas (from 10 to 100 ha) showed a positive trend, while large patches tended to increase in number in the period analyzed in Argentina and Paraguay. For Bolivia, trends were not evident (Fig. 7).

\section{Discussion}

We developed a comprehensive spatially and temporally coherent database on land use transition covering the Dry Chaco region. The database was constructed identifying individual plots through time and using the same identification protocol from 1976 to 2012. The spatially explicit description of the dynamics of transformed areas is an indispensable tool for natural resources management, territorial planning and deforestation impacts research, among others. This geo-database has already been used in academic studies, to detect illegal deforestation (Redaf, 2012), and to support legal disputes in aboriginal territories in Argentina (see bestp.agro.uba.ar/), among other uses. The database is available online at http://monitoreodesmonte.com.ar/for further studies.

The original vegetation, particularly dry forests, of the Dry Chaco is being rapidly replaced by extensive croplands and pastures at an alarming rate (Volante et al., 2012; Hansen et al., 2013). Our study revealed that the rates of deforestation had an increasing trend from 1976 to 2012 (Figs. 2, 3 and 4). In the last period analyzed the Annual Rate of Transformation $q \%$ for the entire region increased 1.7 times, from $0.62 \%$ to $1.02 \%$. Changes in $q \%$ were spatially heterogenous. Although at the country level trends were always positive, the magnitude of the increase in the last six years varied: in Paraguay $q \%$ increased 3.4 times (from $0.72 \%$ to $2.44 \%$ ), in Bolivia increased 1.7 times (from $0.15 \%$ to $0.25 \%$ ), and in Argentina increased 1.12 times (from $0.76 \%$ to $0.85 \%$ ) (Fig. 4). Changes were also variable at the second administrative level analyzed. In the last period analyzed the Annual Rate of Transformation was still increasing in Argentina in several provinces (Formosa, Jujuy, Salta, San Luis and Santiago del Estero). In Formosa the Annual Rate of Transformation increased 8.2 times in the last decade (from $0.09 \%$ to $0.8 \%$ ), and in Salta, 1.6 times (from $0.86 \%$ to $1.40 \%$ ) (Fig. $3 \mathrm{~b}$ ). Other provinces showed decreasing trends in the Annual Rate of Transformation (Catamarca, Chaco, Córdoba, Santa Fe and Tucumán). These decreasing trends in deforestation may be associated with two facts: a) much of the remaining forest lands in those provinces 
Table 1

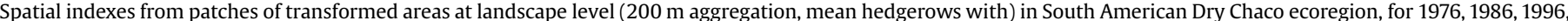

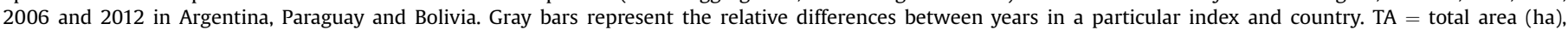

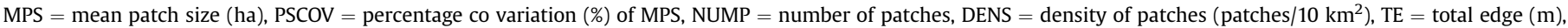
MSI = Mean Shape Index.

\begin{tabular}{|c|c|c|c|c|c|c|c|}
\hline Year & TA (ha) & MPS (ha) & PSCOV (\%) & NUMP & DENS & TE (m) & MSI \\
\hline 1976 & 2.543 .280 & 715 & 10 & 3.556 & 0,76 & 11.598 & 1,51 \\
\hline 1986 & 4.520 .474 & 872 & 12 & 5.182 & 1,11 & 13.584 & 1,55 \\
\hline 1996 & 5.845 .509 & 1.130 & 12 & 5.172 & 1,11 & 15.935 & 1,57 \\
\hline 2006 & 9.046 .075 & 1.577 & 14 & 5.738 & 1,23 & 18.650 & 1,55 \\
\hline 2012 & 11.010 .087 & 1.828 & 14 & 6.023 & 1,29 & 20.385 & 1,54 \\
\hline 1976 & 31.885 & 375 & 2 & 85 & 0,07 & 10.441 & 1,64 \\
\hline 1986 & 70.541 & 226 & 6 & 312 & 0,26 & 6.261 & 1,50 \\
\hline 1996 & 198.764 & 251 & 12 & 792 & 0,65 & 6.319 & 1,52 \\
\hline 2006 & 362.310 & 364 & 11 & 994 & 0,81 & 7.366 & 1,54 \\
\hline \multirow{5}{*}{$\begin{array}{l}\frac{2}{4} \\
\frac{1}{3} \\
\frac{1}{4} \\
\frac{\alpha}{4}\end{array}$} & 526.281 & 474 & 11 & 1.110 & 0,91 & 8.718 & 1,56 \\
\hline & 220.791 & 1.110 & 6 & 199 & 0,11 & 26.286 & 1,86 \\
\hline & 864.945 & 2.016 & 9 & 429 & 0,25 & 33.710 & 1,72 \\
\hline & 1.919 .700 & 2.344 & 13 & 819 & 0,47 & 30.604 & 1,65 \\
\hline & 4.491 .473 & 3.790 & 13 & 1.185 & 0,68 & 42.856 & 1,71 \\
\hline 2012 & 7.381 .943 & 4.605 & 13 & 1.603 & 0,92 & 47.446 & 1,68 \\
\hline
\end{tabular}

are located in areas with topographic, edaphic or climatic limitations for agriculture; b) the implementation of the Native Forest Protection Act-Law No. 26,331-, in November 2007, which restricted deforestation in some areas of high and medium conservation value. These results are consistent with those found by UMSEF (2012).

The Dry Chaco has large areas with suitable conditions for producing highly demanded commodities: crops such as soybean and maize, and meat from cultivated pastures (Aizen et al., 2009; Glatzle, 1999). The sharp increase in the prices of these commodities in the last fifteen years (FAOSTAT, 2010; Gasparri et al., 2013; Aide et al., 2012) has led to a rapid expansion in the region. Additionally, changes in local currency exchange rates, the availability of technological packages (no-tillage system and genetically modified crops), and regional increases in precipitation (Boletta et al., 2006; Gasparri et al., 2008; Zak et al., 2004) prompted abrupt changes in the rates of deforestation.

Different groups of land users have a strong imprint on the configuration of landscapes (Killeen et al., 2008; Baldi et al., this issue). The transformation plots size gives an idea of the management unit and it is a proxy of the economic dimension of the actors driving the transformation. In Argentina and Paraguay, where there is a predominance of capitalized farmers and ranchers (Gasparri et al., 2013; Baldi et al., this issue), large plots predominate (Fig. 5), and its size increased from 1976 to 2012 (Fig. 6). This pattern suggests the operation of large land holdings (Steininger et al., 2001; Killeen et al., 2008; Gasparri et al., 2013) and a high level of mechanization for deforestation and sowing (Pacheco and Mertens, 2004; Huang et al., 2009). In Bolivia the situation differed from Argentina and Paraguay because the areas deforested for agriculture are managed by a more diverse group of stakeholders (Pacheco, 2004; Redo et al., 2012). The Chaco region of Bolivia, where there is a predominance of aboriginal groups and non-mechanized Mennonite settlers (Baldi et al., this issue), presented a significantly smaller mean plot size (Figs. 1 and 5) than the Argentine and Paraguayan Chaco. In Bolivia a significant increase in the relative frequencies of small transformed plots throughout the period studied was observed (Fig. 6).

The spatial configuration of the transformed patches (plots aggregated at $200 \mathrm{~m}$ ) changed substantially during the study period between 1976 and 2012. The mean patch size, the number of transformed patches, the density of patches and the total edge increased considerably as the total area transformed increased (Table 1). These results are consistent with other analyses of landscape changes of dry forest areas (Steininger et al., 2001; Gasparri and Grau, 2009; Pinto-Ledezma and Rivero Mamani, 2013). Mean shape index was higher for Paraguay than for Argentina and Bolivia, indicating more complexity (i.e. less compactness) in the deforested patches. Big patches tended to augment in Paraguay, while in Argentina and Bolivia patch size was more stable. The increase in the size of deforested patches suggests a homogenization of the landscape (Fig. 7). The total transformed area, the size of the deforested patches, the total edge and the shape of the patches have large impact on ecosystem functioning (Volante et al., 2012), on local populations, due to habitat loss (Macchi et al., 2013), and on local climate (Camargo and Kapos, 1995; AlcarazSegura et al., 2013b).

Large-scale conversion of Dry Chaco forests into pastures or annual crops accelerates climate changes (Agrawal et al., 2011), alters the ecosystem functioning (Volante et al., 2012) and lead to social problems (Redaf, 2012). In the Dry Chaco more than 20 native ethnic groups coexist. These groups have no definitive tenure of their lands (Leake and De Economo, 2008) and are being displaced from their homeland by the agricultural expansion, increasing territorial conflicts associated to the process that Harvey (2003) defined as "accumulation by dispossession". Monitoring is a key element to start solving the territorial conflict installed by agricultural expansion. On one hand a proper description of the spatial and temporal patterns of land transformation would allow to identify the biophysical, social, political and economic drivers of changes. On the other hand monitoring is essential to develop and enforce land use planning and management policies. 

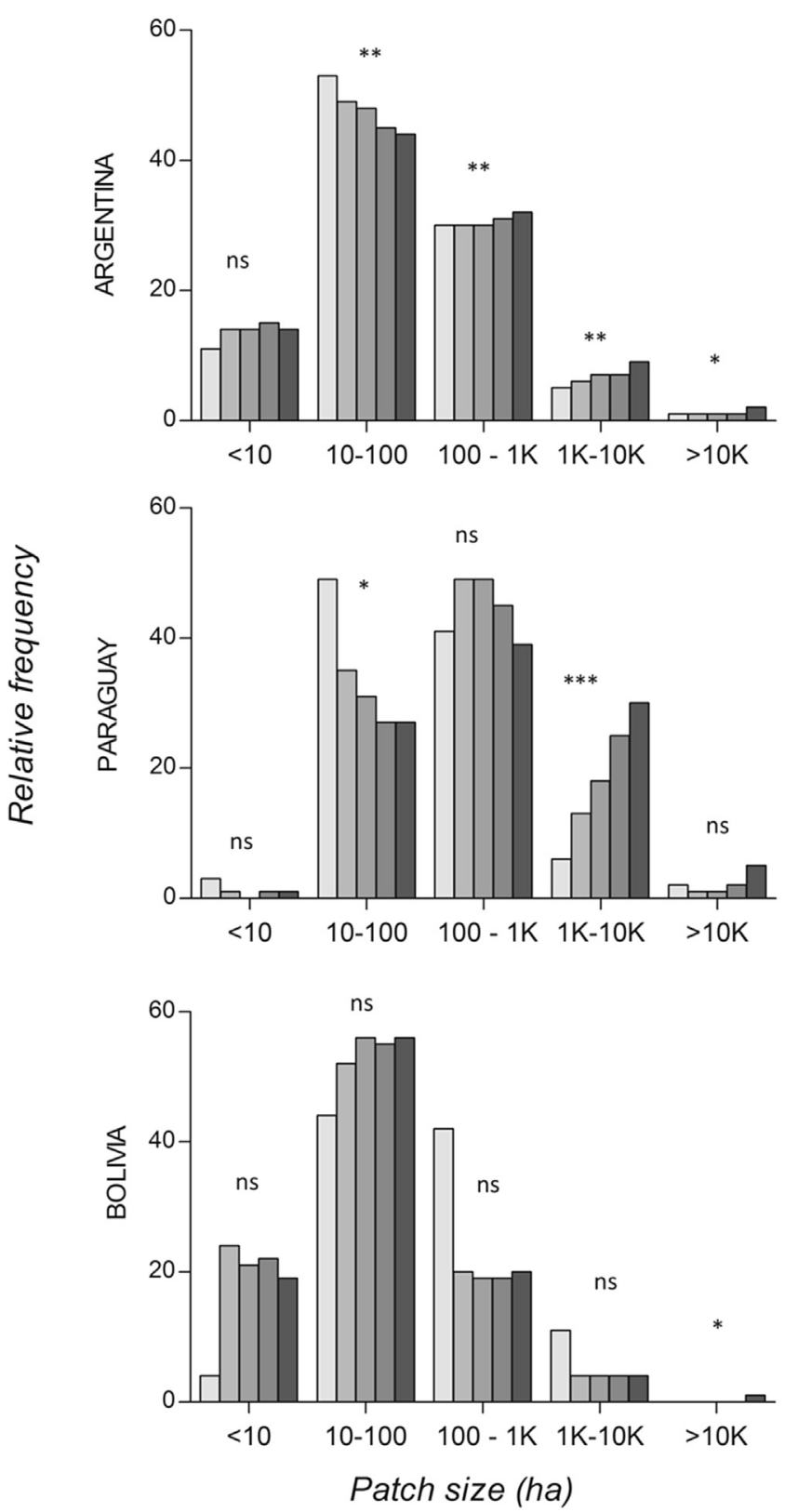

Fig. 7. Relative frequency (to each year) distribution for different patch sizes categories of transformed areas (plots aggregated at $200 \mathrm{~m}$ ) at landscape level from 1976 to 2012 at country level in South American Dry Chaco ecoregion. ns: not significative regression, ${ }^{*}: p<0.5,{ }^{* *}: p<0.05,{ }^{* * *}: p<0.01$.

\section{Uncited reference}

\section{Zak et al., 2008.}

\section{Acknowledgments}

This research was supported by CONICET, REDAF (Proyecto NATIVO, Bosques y su Gente), UBACyT, UBANEX, FONCyT, and INTA. The students that participated in the project "UBANEX bicentenario" contributed to the processes of digitizing transformed plots. This work was carried out with the aid of a grant from the InterAmerican Institute for Global Change Research (IAI) CRN III 3095, which is supported by the US National Science Foundation (Grant GEO-1128040).

\section{Appendix A. Supplementary data}

Supplementary data related to this article can be found at http:// dx.doi.org/10.1016/j.jaridenv.2014.11.009.

\section{References}

Achard, F., Eva, H.D., Stibig, H.J., Mayaux, P., Gallego, J., Richards, T., Malingreau, J.P., 2002. Determination of deforestation rates of the world's humid tropical forests. Science 297 (5583), 999-1002.

Agrawal, A., Nepstad, D., Chhatre, A., 2011. Reducing emissions from deforestation and forest degradation. Annu. Rev. Environ. Resour. 36, 373-396.

Aide, T.M., Clark, M.L., Grau, R.H., López-Carr, D., Levy, M.A., Redo, D., BonillaMoheno, M., Riner, G., Andrade-Núñez, M.J., Muñiz, M., 2012. Deforestation and reforestation of Latin America and the Caribbean (2001-2010). Biotropica 0 (0), $1-10$.

Aizen, M.A., Garibaldi, L.A., Dondo, M., 2009. Expansión de la soja y diversidad de la agricultura argentina. Ecol. Aust. 19, 45-54.

Alcaraz-Segura, D., Paruelo, J.M., Epstein, H.E., Cabello, J., 2013a. Environmental and human controls of ecosystem functional diversity in temperate south America. Remote Sens. 5 (1), 127-154.

Alcaraz-Segura, D., Berbery, H.E., Müller, O.V., Paruelo, J.M., 2013b. Characterizing and monitoring climate regulation services. In: Alcaraz-Segura, D., Di Bella, C.M., Straschnoy, J.V. (Eds.), Earth Observation of Ecosystem Services. CRC Press, p. 518.

Amdan, M.L., Aragón, R., Jobbágy, E.G., Volante, J.N., Paruelo, J.M., 2013. Onset of deep drainage and salt mobilization following forest clearing and cultivation in the Chaco plains (Argentina). Water Resour. Res. 49, 1-12.

Andaluz, A.W., Mancilla, R.T., 2006. Análisis nacional preliminar sobre gobernabilidad y cumplimiento de la legislación en el sector forestal de Bolivia. The World Bank, Washington, D.C.

Baldi, G., Guerschman, J.P., Paruelo, J.M., 2006. Characterizing fragmentation in temperate South America grasslands. Agric. Ecosyst. Environ. 116, 197-208.

Baldi, G., Houspanossian, J., Murray, F., Rosales, A.A., Rueda, C.V and Jobbágy, E.G. (in this issue). Cultivating the dry forests of South America: diversity of land users and imprints on ecosystem functioning. J. Arid Environ.

Berbery, E.H., Barros, V.R., 2002. The hidrologic cicle of the plata Basin in south America. Repr. J. Hydrometeorol. 3 (6), 628-645.

Bhanu, B., Lee, S., Ming, J., 1995. Adaptive image segmentation using a genetic algorithm. IEEE Trans. Syst. Man Cybern. 25 (12), 1543-1567.

Boletta, P.E., Ravelo, A.C., Planchuelo, A.M., Grilli, M., 2006. Assessing deforestation in the Argentine Chaco. For. Ecol. Manag. 228, 108-114.

Bolsi, A., Paolasso, P., 2009. La pobreza entre los argentinos del Norte Grande. Cienc. Hoy 19 (111), 8-17.

Briant, G., Gond, V., Laurance, S.G.W., 2010. Habitat fragmentation and the desiccation of forest canopies: a case study from eastern Amazonia. Biol. Conserv. 143 (11), 2763-2769.

Broadbent, E.N., Asner, G.P., Keller, M., Knapp, D., Oliveira, P.J.C., Silva, J.N., 2008 Forest fragmentation and edge effects from deforestation and selective logging in the Brazilian Amazon. Biol. Conserv. 141, 1745-2175.

Caballero, J., Palacios, F., Arévalos, F., Rodas, O., Yanosky, A., 2014. Cambio de Uso De La Tierra en el Gran Chaco Americano en el año 2013. Paraquaria Nat. 2 (1), 21-28.

Caldas, M.M., Goodin, D., Sherwood, S., Campos Krauer, J.M., Wisely, S.M., 2013 Land-cover change in the Paraguayan Chaco: 2000-2011. J. Land Use Sci. 1-18.

Camargo, J.L.C., Kapos, V., 1995. Complex edge effects on soil moisture and microclimate in central Amazonian forest. J. Trop. Ecol. 11, 205-221.

Cardozo, R., Palacios, F., Rodas, O., Yanosky, A., 2013. Cambio de Uso De La Tierra en el Gran Chaco Americano en el año 2012. Paraquaria Nat. 1 (2), 43-49.

Clark, M.L., Aide, T.M., Grau, H.R., Riner, G., 2010. A scalable approach to mapping annual land cover at $250 \mathrm{~m}$ using MODIS time series data: a case study in the dry chaco ecoregion of South America. Remote Sens. Environ. 114, 2816-2832.

Fahrig, L., 2003. Effects of habitat fragmentation on biodiversity. Annu. Rev. Ecol. 34, 487-515.

FAO (Food Agriculture Organization of the United Nations), 1995. Forest Resources Assessment 1990. In: Global Sintheis. Forestry Paper, vol. 124. FAO, Rome.

FAO (Food Agriculture Organization of the United Nations), 2009. State of the World's Forests. FAO, Roma, Italia., p. 168

FAOSTAT., 2010. FAOSTAT Database [online]. Available at: http://faostat.fao.org.

Fundación Avina, Abril 2012. Monitoreo de los cambios de uso de la tierra, incendios e inundaciones del gran chaco. Informe Final Técnico años 2010-1012. Asunción.

García Collazo, M.A., Panizza, A., Paruelo, J.M., 2013. Ordenamiento Territorial de Bosques Nativos: Resultados de la Zonificación realizada por provincias del Norte argentino. Ecol. Aust. 23, 97-107.

Gasparri, I.N., Grau, H.R., 2009. Deforestation and fragmentation of Chaco dry forest in NW Argentina (1972-2007). For. Ecol. Manag. 258, 913-921.

Gasparri, I.N., Grau, H.R., Manghi, E., 2008. Carbon pools and emissions from deforestation in extra-tropical forests of northern Argentina between 1900 and 2005. Ecosystems 11, 1247-1261.

Gasparri, N.I., Grau, H.R., Gutiérrez Angonese, J., 2013. Linkages between soybean and neotropical deforestation: coupling and transient decoupling dynamics in a multi-decadal analysis. Glob. Environ. Change 23 (6), 1605-1614. 
GCOS, 2004. Implementation Plan for the Global Observing System for Climate in Support of the UNFCCC. GCOS-92 (WMO/TD No. 1219). Global Climate Observing system, Geneva.

Glatzle, A., 1999. Compendio para el manejo de pasturas en el Chaco. El Lector. Estación Experimental Chaco Central, Paraguay.

GOFC-GOLD, 2007. Global Observation of Forests and Land Cover Dynamics. http:/ www.fao.org/gtos/gofc-gold/index.html.

Grau, H.R., Gasparri, I.N., Aide, T.M., 2005. Agriculture expansion and deforestation in seasonally dry forests of north-west Argentina. Environ. Conserv. 32. $140-148$.

Hansen, M.C., Potapov, P.V., Moore, R., Hancher, M., Turubanova, S.A., Tyukavina, A., Thau, D., Stehman, S.V., Goetz, S.J., Loveland, T.R., Kommareddy, A., Egorov, A. Chini, L., Justice, C.O., Townshend, J.R.G., 2013. High-resolution global maps of 21st-Century Forest cover change. Science 342, 850-853.

Harvey, D., 2003. The New Imperialism. Oxford University Press, Oxford.

Huang, C., Kim, S., Song, K., Townshend, J.R.G., Davis, P., Altstatt, A., Rodas, O. Yanosky, A., Clay, R., Tucker, C.J., Musinsky, J., 2009. Assessment of Paraguay's forest cover change using landsat observations. Glob. Planet. Change 67, 1-12.

INPE., 2008. Monitoramento da floresta Amazônica Brasileira por Satélite. Projeto PRODES. http://www.obt.inpe.br/prodes.

Jobbágy, E.G., Nosetto, M.D., Santoni, C.S., Baldi, G., 2008. El desafío eco hidrológico de las transiciones entre sistemas leñosos y herbáceos en la llanura ChacoPampeana. Ecol. Aust. 18, 305-322.

Killeen, T.J., Guerra, A., Calzada, M., Correa, L., Calderon, V., Soria, L., Quezada, B. Steininger, M.K., 2008. Total historical land-use change in eastern Bolivia: who, where, when, and how much? Ecol. Soc. 13, 36

Lambin, E.F., Gibbs, H.K., Ferreira, L., Grau, H.R., Mayaux, P., Meyfroidt, P., Morton, D.C., Rudel, T.K., Gasparri, I., Munger, J., 2013. Estimating the world's potentially available cropland using a bottom-up approach. Glob. Environ. Change 23, 892-901.

Leake, A., De Economo, M., 2008. La deforestación de Salta 2004-2007. Fundación Asociana, Editorial Milor, Salta, Argentina.

Macchi, L., Grau, H.R., Zelaya, P.V., Marinaro, S., 2013. Trade-offs between land use intensity and avian biodiversity in thedry chaco of Argentina: a tale of two gradients. Agric. Ecosyst. Environ. 174, 11-20.

McGarigal, K., Cushman, S.A., Neel, M.C., Ene, E., 2002. FRAGSTATS: Spatial Pattern Analysis Program for Categorical Maps. Computer software program produced by the authors at the University of Massachusetts, Amherst. Available at: http:// www.umass.edu/landeco/research/fragstats/fragstats.html.

Minetti, J.L., 1999. Atlas Climático del Noroeste Argentino. Laboratorio Climatológico Sudamericano. Fundación Zona Caldenius, Tucumán, Argentina.

Morello, J., Pengue, W., Rodriguez, A., 2005. Etapas de uso de los recursos y desmantelamiento de la biota del Chaco. Fronteras 4, 1-17.

Morello, J., Matteucci, S.D., Rodriguez, A.F., Silva, M.E., 2012. Ecorregiones y complejos ecosistemicos argentinos. Primera ed. Facultad de Arquitectura Desarrollo y Urbanismo, Buenos Aires, Argentina, p. 752.

Naumann, M., 2006. Atlas del Gran Chaco Sudamericano. In: Sociedad Alemana de Cooperación Técnica (GTZ). ErreGé\&Asoc, Buenos Aires, p. 92.

Olson, D.M., Dinerstein, E., Wikramanayake, E.D., Burgess, N.D., Powell, G.V.N., Underwood, E.C., D'Amico, J.A., Itoua, I., Strand, H.E., Morrison, J.C., Loucks, C.J., Allnutt, T.F., Ricketts, T.H., Kura, Y., Lamoreux, J.F., Wettengel, W.W., Hedao, P., Kassem, K.R., 2001. Terrestrial ecoregions of the world: a new map of life on Earth. BioScience 51 (11), 933-938.

O'Neill, R.V., Hunsaker, C.T., Jones, K.B., Riitters, K.H., Wickham, J.D., Schwartz, P.M. Goodman, I.A., Jackson, B.L., Baillargeon, W.S., 1997. Monitoring environmental quality at the landscape scale. BioScience 47, 513-519.

Pacheco, P., 2004. Las fronteras agrícolas en el trópico boliviano: entre las situaciones heredadas y los desafíos del presente. Centro de Investigación Forestal Internacional (CIFOR), Investigador asociado, Instituto de Pesquisa Ambienta da Amazonia (IPAM),Brasil, Indonesia.
Pacheco, P., Mertens, B., 2004. Land use change and agricultural development in Santa Cruz, Bolivia. Bois Forêts des Trop. 280 (2), 29-40.

Paolasso, P., Bolsi, A., Gasparri, I., Longhi, F., 2012. La pobreza en el nordeste argentino: cambios y persistencias durante la primera década del siglo XXI, pp. 111-136. Estudios y contribuciones en homenaje a la doctora Norma Cristina Meichtry, Ed. Con Texto. Resistencia.

Paruelo, J.M., Verón, S.R., Volante, J.N., Seghezzo, L., Vallejos, M., Aguiar, S., Amdan, L., Baldassini, P., Davanzo, B., González, E., Landesmann, J., Picardi, D., 2011. Elementos conceptuales y metodológicos para la Evaluación de Impactos Ambientales Acumulativos (EIAAc) en bosques subtropicales. El caso del este de Salta, Argentina. Ecol. Aust. 21, 163-178.

Pielke, R.A., Avissar, R., 1990. Influence of landscape structure on local and regional climate. Landsc. Ecol. 4, 133-155.

Pinto-Ledezma, J.N., Rivero Mamani, M.L., 2013. Temporal patterns of deforestation and fragmentation in lowland Bolivia: implications for climate change. Clim. Change. http://dx.doi.org/10.1007/s10584-013-0817-1.

Pinto-Ledezma, J.N., Ruiz, T., 2010. Deforestación y fragmentación 1976-2006 en el municipio de San Julián (Santa Cruz, Bolivia). Ecol. Boliv. 45 (2), 101-115.

Red Agroforestal Chaco Argentina (REDAF), Diciembre, 2012. Monitoreo de Deforestación en los Bosques Nativos de la Región Chaqueña Argentina. Informe $\mathrm{N}^{\circ} 1$. Ley de Bosques, análisis de deforestación y situación del Bosque chaqueño en la provincia Observatorio de Tierras, Recursos Naturales y Medioambiente, Bosque Nativo en Salta.

Redo, D.J., Grau, H.R., Aide, T.M., Clarck, M.L., 2012. Asymmetric forest transition driven by the interactionof socioeconomic development and environmental heterogeneity in Central America. PNAS 109 (23), 1-6.

Riitters, K.H., O'Neill, R.V., Hunsaker, C.T., Wickham, J.D., Yankee, D.H., Timmins, S.P. Jones, K.B., Jackson, B.L., 1995. A factor analysis of landscape pattern and structure metrics. Landsc. Ecol. 10, 23-39.

Saunders, D.A., Hobbs, R.J., Margules, C.R., 1991. Biological consequences of ecosystem fragmentation: a review. Conserv. Biol. 5, 18-32.

Seghezzo, L., Volante, J.N., Paruelo, J.M., Somma, D.J., Buliubasich, E.C., Rodriguez, H.E., Gagnon, S., Hufty, M., 2011. Native forests and agriculture in salta (Argentina): conflicting visions of development. J. Environ. Dev. 20 (3), 251-277.

Shimabukuro, Y.E., Duarte, V., Anderson, L.O., Arai, E., Valeriano, D.M., Espírito Santo, F.D.B., Aulicino, L.C.M., 2004. Deforestation Detection in Brazilian Amazon Region in a near Real Time Using Terra MODIS Daily Data. In: Geoscience and Remote Sensing Symposium, IGARSS '04, vol. 5, pp. 3405-3408.

Steininger, M.K., Tucker, C., Townshend, J.R., Killeen, T., Desch, A., Bell, V., Ersts, P., 2001. Tropical deforestation in the Bolivian Amazon. Environ. Conserv. 28 127-134.

The Nature Conservancy (TNC), Fundación Vida Silvestre Argentina (FVSA), Fundación para el Desarrollo Sustentable del Chaco (DeSdel Chaco) y Wildife Conservation Society Bolivia (WCS), 2005. Evaluación Ecorregional del Gran Chaco Americano/Gran Chaco Americano Ecoregional Assessment. Fundación Vida Silvestre Argentina, Buenos Aires, p. 26.

UMSEF, 2012. Monitoreo de la Superficie de Bosque Nativo de la República Argentina Período 2006-2011 (Regiones forestales Parque Chaqueño, Selva Misionera y Selva Tucumano Boliviana. Buenos Aires, Argentina).

Volante, J.N., Alcaraz-Segura, D., Mosciaro, J.M., Viglizzo, E.F., Paruelo, J.M., 2012. Ecosystem functional changes associated with land clearing in NW Argentina. Agric. Ecosyst. Environ. 154, 12-22.

Volante, J.N. and Paruelo, J.M. (in this issue). Is forest transition taking place? evidence for the semiarid Chaco in Argentina. J. Arid Environ.

Zak, M.R., Cabido, M., Hodgson, J.G., 2004. Do subtropical seasonal forests in the Gran Chaco, Argentina, have a future? Biol. Conserv. 120, 589-598.

Zak, M.A., Cabido, M., Cáceres, D., Díaz, S., 2008. What drives accelerated land cover change in Central Argentina? synergistic consequences of climatic, socioeconomic, and technological factors. Environ. Manag. 42, 181-189. 